\title{
渗出性中耳炎の発症に和敌る細菌之免疫防御の関係
}

\author{
訔良博・垣内弘・神人崇 \\ 加藤 寛・田端 敏秀
}

\section{Relation between Bacterial Infection and Host Immune Defense in the Pathogenesis of Otitis Media with Effusion}

\author{
Yoshihiro Dake, Hiromu Kakiuchi, Takashi Jinnin, \\ Yutaka Katoh and Toshihide Tabata \\ (Wakayama Medical College)
}

\begin{abstract}
S. pneumoniae has been identified as one of the major pathogens on acute otitis media. It has been shown that the specific antibody against the pathogen protects the middle ear infection and the prolongation of inflammation in animal models. We will review the mechanism of the pathogenesis of otitis media with effusion from viewpoint of the immune defense to bacteria. Childeren with recurrent otitis media have low levels or a deficency of IgG2 subclass and low pneumococcal antibody titer. In chronic otitis media with effusion, pneumococcal anti-IgG antibody levels were low in infants and rose with increasing age. There were no abnormal IgG subclass value. This suggests that an antibody production system against bacterial invasion may not be fully developed in infants and a delayed immune response may associate with otitis media.
\end{abstract}

Key words: otitis media with effusion, bacterial infection, S. pneumoniae, humoral immunity, IgG subclass

1867年 Politzer ${ }^{1)}$ が渗出性中耳炎を報告して 以来その発症機序は, 耳管機能障害による補空 現象と考えられてきた。しかし, 細菌学の進歩 と免疫学の発達また疫学的調査によって感染・ 炎症, 免疫・アレルギー, 周辺蔵器である口蓋 扁桃・アデノイドや鼻副鼻腔炎などとの関係が 重要であることが判明してきた。このように滲 出性中耳炎の発症には種々の因子が複雑に絡み 合いその機序は一元的なものではない，本稿は 著者の研究を中心に細菌感染の立場から急性中
耳炎と渗出性中耳炎の関係を述べ，その発症機 序について動物実験モデルを含めて細菌感染防 御能の観点から論じることとした.

\section{I ．急性中耳炎との関係}

従来，滲出性中耳炎貯留液の細菌培養が陰性 であるため, 細菌感染とは無関係であると考え られてきた。しかし，細菌学の進歩と細菌同定 への免疫学的応用によって貯留液が必ずしも無 菌でないことが判明した (Senturia ${ }^{2)}$ ，1958). 滲 出性中耳炎貯留液より分離される細菌は， H. 
influenzae, S. pneumoniae, S. aureus, B. catarrhalis (Sade ${ }^{3)}, 1979$, Bluestone and Klein ${ }^{4)}$, 1988）などが同定されている，さらに細菌培養 陰性貯留液においても H． influenzae などの グラム陰性菌の内毒素であるエンドトキシン (DeMaria ${ }^{5)}$, 1984, 飯野6), 1984, 獄7), 1985) や S. pneumoniae の萊膜抗原 (Palva ${ }^{8) 9)}, 1983$, 1985, 原田10)，1984，嶽11)，1988）が検出されて いる。これらの細菌は急性中耳炎の主要な起炎 菌でもある。しかも慢性滲出性中耳炎患児の疫 学調査にて, Kokko ${ }^{22)}$ (1974) は滲出性中耳炎患 児の $63.4 \%$ が化膿性中耳炎を経験していたと報 告している. Teele ${ }^{13)}$ (1980) も 3 歳までに71\% の小児が急性中耳炎の既往歴があり，急性中耳 炎罹患 2 週間後では70\%に中耳貯留液を認め, 1 力月後では $40 \%$ に，2 力月後では20\%に，3 カ月後でも $10 \%$ に中耳貯留液が存在することを 指摘している.Kaneko ${ }^{14)}$ (1983) は初回急性中 耳炎後の滲出性中耳炎発症頻度を検討し， 1 年 以内に $14.3 \% ， 2$ 年以内に $25.6 \%$ が発症すると 報告している．これらのことより渗出性中耳炎 の発症に急性中耳炎との関係が強く示唆され， 急性中耳炎から渗出性中耳炎へと移行していく 可能性が考兄られる。しかし急性中耳炎から慢 性渗出性中耳炎に約10２0\%が移行するにして も，滲出性中耳炎に移行する小児と治癒する小 児のどこに違いがあるのかが問題となる，その 個体差の大きな因子として細菌感染に対する防 御能を検討する必要がある。

\section{II. 実験的中耳炎モデル}

そこでこれら急性中耳炎の主要な起炎菌を用 いた実験的中耳炎モデルの研究がなされた．H. influenzae を用いた実験には Fulghum ${ }^{15)}$ (1985), Mills $^{16)}$ (1986), Barenkamp ${ }^{17)}$ (1986) らの報告 があり，S． pneumoniae を用いた実験には Giebink $^{1819)}$ (1976, 1977), Meyerhoff ${ }^{20)}$ (1980), Fulghum $^{21)}$ (1985), Hermansson ${ }^{22)}$ (1988) らの報 告がある. 動物はモルモット，ラット，チンチ ラなど異なるがその結果は動物種によって細菌 感受性の差はあるものの化膿性中耳炎を引き起
こした。しかし興味あることに Type 3 肺炎球 菌の方が，Group 6 や23肺炎球菌に比して強い 粘膜炎症を惹起し，長期間炎症が持続したこと である，肺炎球菌の血清型の違いによって中耳 粘膜反応の相違が認められた。

肺炎球菌は83 血清型に分類され, Type 3, Group 6, Group 19, Group 23 などで急性中耳 炎に検出される肺炎球菌の55.3\%（村井 ${ }^{23}$, 1988)，55.9\%（福見24，1984），70.2\%（獄25), 1989）と本邦では報告されている。これは欧米 の頻度 $56.0 \%{ }^{4)} ， 74.0 \%$ (Leinonen $^{26)}$ ，1980) と 類似している。 また抗原性の点でも血清型によ って異なることが指摘されている．乳児と低年 秢の小児では Type $6 \mathrm{~A}$ が poor immunogen, Type 3 が good immunogen, Type 19F が中間

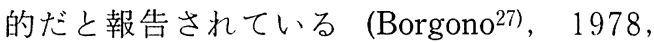
Cowan ${ }^{28)}, 1978$, Pedersen $\left.{ }^{29)}, 1982\right)$. Watanabe ${ }^{30)}$ (1982) は Type 3 の方が Type 23 より抗原性が 強いことを実験的肺炎球菌性中耳炎モデルで示 した。著者 ${ }^{31)}$ (1989）\& Type 3, Group 19, Group 23 肺炎球菌を用いて，その血清型と菌 量による中耳炎の経過をモルモットによる動物 実験で観察した. Type 3 肺炎球菌は数十個で も中耳炎を発症させることができた。 Type 3, Group 19 と Group 23 肺炎球菌をそれぞれ数百 個中耳腔に注入した場合, Type 3 肺炎球菌は 強い中耳粘膜炎症を若起した.しかも Group 19 と23肺炎球菌に比べて炎症が遷延化し 3 週目で も中耳腔には膿性分泌物を認め, 骨新生, 線維 増生による肥厚と浸潤細胞を認めた（図 1，図 2 , 図 3 ). Group 23 肺炎球菌は粘膜炎症も弱 く，2 週目に打いては線維化と骨新生は認めら れるもののほ添炎症は消退している. Group 19 は中間的な炎症の強さで 3 週目で炎症は消退し た。

さらにこれら細菌と宿主側の免疫反応につい ても実験的に検討されている. Yamaguchi ${ }^{32)}$ (1986) はインフルェンザ菌をチンチラ中耳腔に 注入後の抗インフルェンザ抗体を経日的に調べ 抗体の上昇を認めている。 しかし抗体の存在に 
もかかわらず，インフルェンザ菌が中耳腔内に 存在することに対して多核白血球の機能障害や 線毛上皮の機能障害の可能性を考光ているがそ
の機序については定かではない。一方, Barenkamp ${ }^{33)}$ (1986) は Nontypable H. influenzae に対する抗血清をチンチラに静注すること

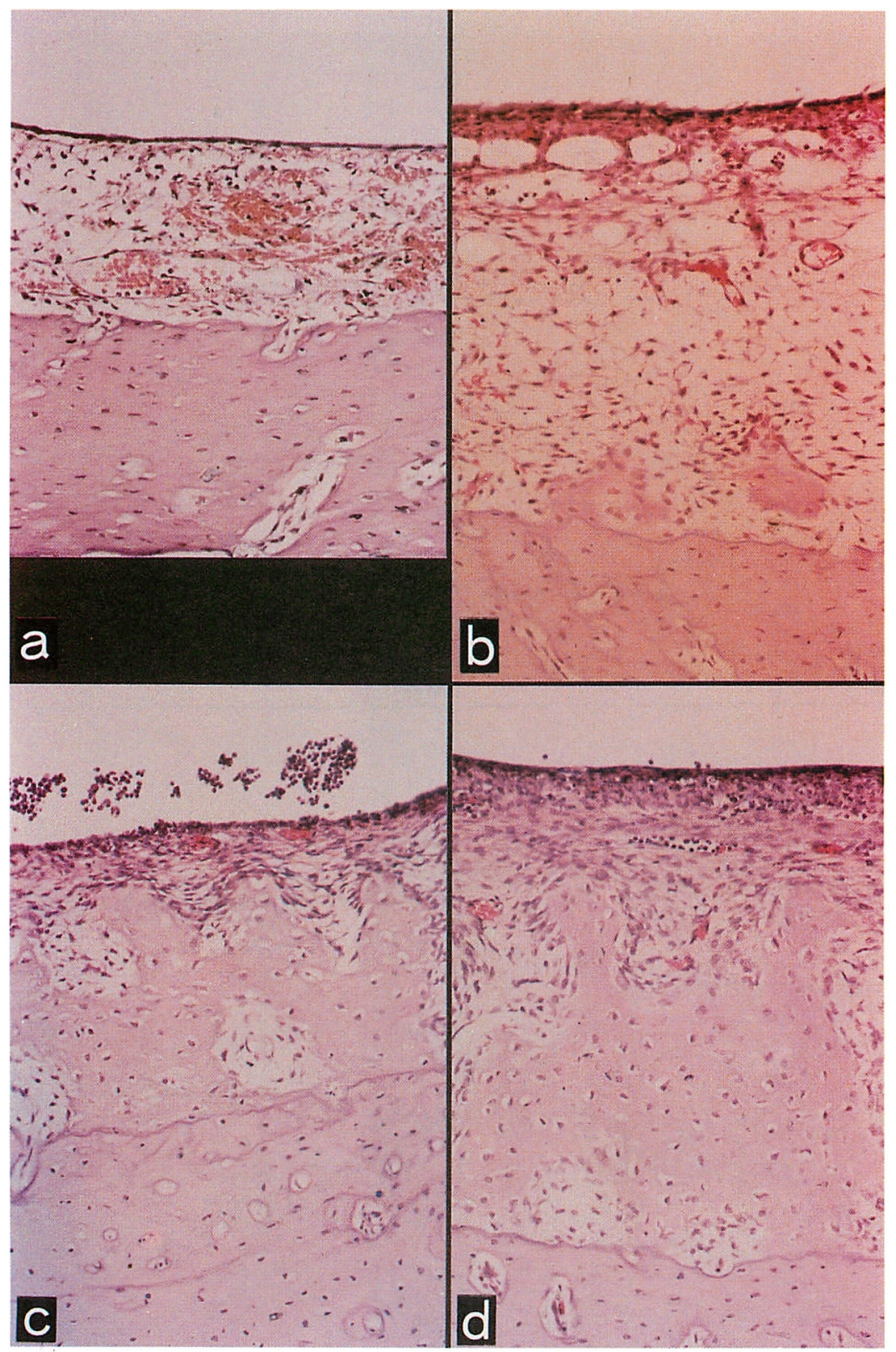

図 1 Type 3 肺炎球菌を数百個中耳腔に注入後の粘膜変化 $(\times 100)$

a ：3 日目では好中球浸潤, 粘膜浮腫とリン八管据張を認める。b：7 日目でも好中球浸潤があり, リンパ管拡張と線維，骨新生をみる。c：14日目でも好中球が単核球と共に存在し，粘膜は骨新生 により肥厚する。d：21日目でる浸潤細胞を認める。 
により,インフルェンザ菌の中耳腔注入後の中 耳炎発症を予防できたと報告している。また Shurin $^{34)}$ (1988) は肺炎球菌多糖体に対寸るヒ卜 免疫グロブリンをチンチラに投与して，肺炎球
菌性中耳炎を同じく予防できたと報告している。 このように細菌性中耳炎の発症や予後に影響 寸るのは起炎菌に対する特異的抗体の存在が重 要であることを明らかにしている。また肺炎球

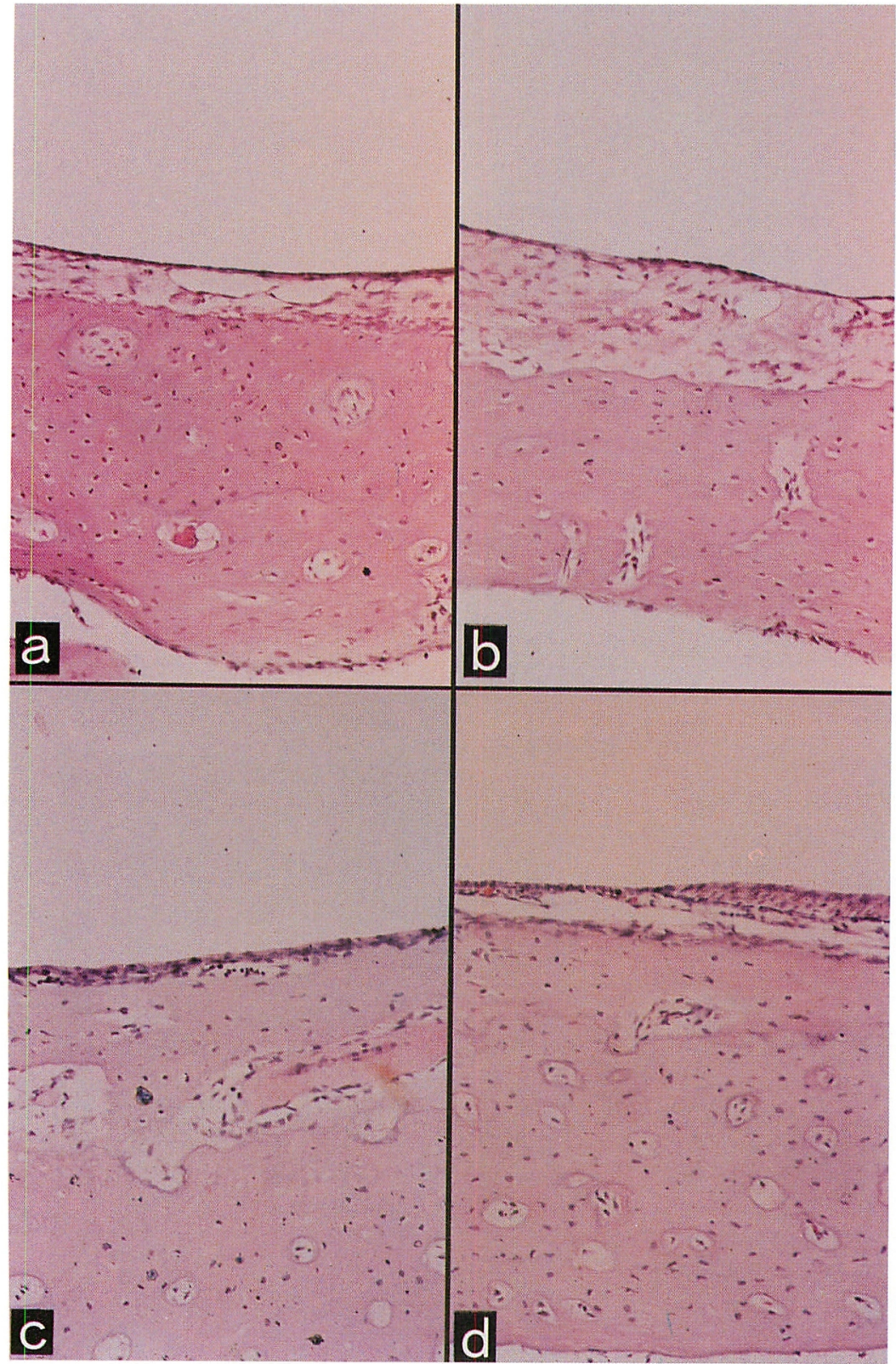

図 2 Group 23 肺炎球菌を数百個中耳腔飞注入後の粘膜变化 $(\times 100)$ a：3日目の粘膜浮腫は軽度である。b：7 日目で粘膜は線維増生してきている。c：14日目では 単核球が散在するが粘膜は骨新生に置換している。d：21日目で炎症は治癒した。 
菌血清型の相違によっても中耳粘膜炎症に差が あることより，ヒト急性中耳炎でも同じように 予後が異なるのかといら点を今後臨床で検討す
る必要がある，以上より細菌の中耳に対しての 炎症反応の違い性体の防御能と関係しておう, 臨床的に急性中耳炎患児のすへでが滲出性中耳

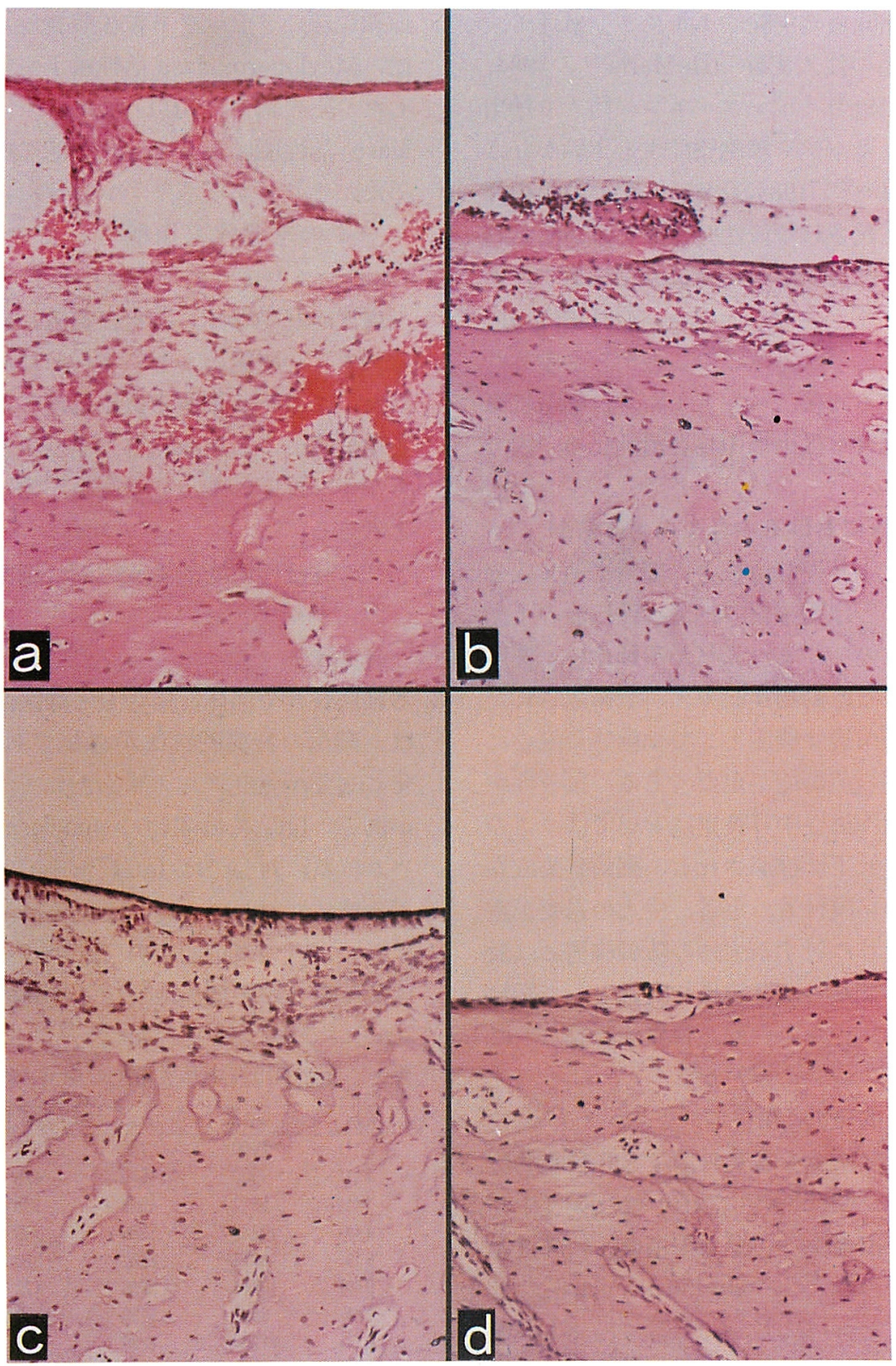

図 3 Group 19 肺炎球菌を数百個中耳腔に注入後の粘膜変化 $(\times 100)$

$\mathrm{a} ： 3$ 日目中耳粘膜の炎症も強く粘膜浮腫と出血を見る。 b : 7 日目でも中耳腔に好中球と膿性分 泌物を認める。c：14日目で単核球の浸潤と線維化を見る。d：21日目で骨新生にて治癒している. しかし粘膜の肥厚は軽度である。 
炎に移行する訳でない理由の一つと考光る.

また生菌ではなく細菌菌体成分が抗原として 中耳炎を惹起するかどうかも実験された。加熱 処理した肺炎球菌をチンチラ中耳腔に注入した Lowel135) (1980) らの実験やホルマリン処理イン

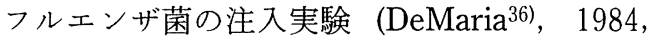
Okazaki37)，1984)，インフルェンザ菌より抽出 したエンドトキシンや細胞壁による実験がなさ れた（野々村38)39），1985，1988）。その結果中耳 粘膜炎症が惹起され漿液性貯留液が確かめられ た.これらは肺炎球菌の萊膜抗原や細菌内産生 酵素によったり，エンドトキシンの直接作用に よるものと考光られる．このことからも中耳貯 留液に存在する死菌, エンドトキン, 細菌抗原 の排除機能障害も渗出性中耳炎遷延化の一因で あるといえる。

\section{III. 臨床における中耳炎と生体防御}

慢性滲出性中耳炎貯留液中に細菌や菌体成分 が存在することは宿主側の細菌排除機能の不完 全性によるもので，またこれが遷延化の一機序 とも考兄られる. 動物実験モデルで確認された ようにこの細菌排除機能として細菌感染成立に 対する宿主側の防御能が重要である．反復性中 耳炎児や慢性滲出性中耳炎児に扣いては，この 感染防御能の低下が推測される．細菌感染成立 には, 細菌の粘膜付着, 定着, 侵入の過程が重 要である。これに対する生体の防御機構には数 多くあるが，ここでは非特異的防御として顆粒 球・マクロファージの役割と特異的防御として の体液性免疫について述べる.

(1) 非特異的防御 (顆粒球，マクロファージ) 多核白血球は細菌を貧食殺菌する非特異的防 御能を有する．Giebink ${ }^{40)}$ (1979) は反復性中耳 炎児と慢性渗出性中耳炎児の末梢血多核球機能 の遊走能，殺菌能，chemiluminescence 活性を 検討し，それぞれ17.5\%，23.3\%，15.8\%の機 能低下を認めた。しかし，それらの機能低下は 一過性のものと考光ている. Ichimura ${ }^{41)}$ (1982) は反復性中耳炎児好中球の遊走能を, 他の反復 性耳下腺炎や習慣性扁桃炎患児の好中球を con- trol として測定した．その結果，他の反復性感 染症に比べて反復性中耳炎患児の好中球機能が 低下していたと報告している.Karvhev"22)(1985) は渗出性中耳炎患児や反復性中耳炎患児の末梢 血顆粒球のラテックス粒子貧食能と NBT 還元 能，Meyloperoxidase 活性による殺菌能を検討 した．その結果， NBT 還元能と Meyloperoxidase 活性能は正常で，貧食能に機能低下を認 めた。 またエンドトキシン処理に係るマクロフ ァージの重要性も指摘されている（飯野43）, 1988）。このように反復性中耳炎や滲出性中耳 炎患児の好中球は，遊走，貧食，細菌殺菌とい った大きな機能のらちいずれかに障害が認めら れた.このため細菌や抗原処理が不完全になり 各種酵素による組織障害や免疫複合体によるア レルギー反応によって中耳炎が遷延化するもの と考学る。

(2) 体液性免疫による防御（細菌特異的免疫 グロブリン)

好中球やマクロファージの opsonin 化によ る細菌貧食や補体と結合して溶菌作用のために は, 細菌の特異的抗体が必要である。 opsonin 化に必要な免疫グロブリンとしては IgG, IgM がある. IgG には 4 つの subclass がありタン パク抗原に対しては IgG1 と IgG3 抗体が，リ ポ多糖体に対して，IgG2 抗体が主に関与して いる. よって末梢血中の IgG subclass や肺炎 球菌萊膜りポ多糖体に対する特異的抗体につい

表 1 慢性滲出性中耳炎患児の血清 IgG subclass 值

\begin{tabular}{crrrr}
\hline age & IgG 1 & IgG 2 & IgG 3 & IgG 4 \\
\hline $1(1)$ & $6000^{*}$ & 780 & 325 & 0 \\
$2(1)$ & 7900 & 1640 & 425 & 90 \\
$3(3)$ & 9567 & 4933 & 388 & 639 \\
$4(7)$ & 10343 & 1886 & 303 & 195 \\
$5(6)$ & 9616 & 2307 & 520 & 192 \\
$6(9)$ & 10444 & 3258 & 472 & 291 \\
$7(3)$ & 9033 & 3020 & 305 & 326 \\
$8(3)$ & 11200 & 2200 & 200 & 167 \\
$9(3)$ & 10166 & 2687 & 376 & 468 \\
$10(3)$ & 12350 & 1780 & 225 & 495 \\
$11(3)$ & 11583 & 2733 & 850 & 286 \\
$12(2)$ & 13100 & 3610 & 322 & 426 \\
\hline
\end{tabular}

( ) mean value in $\mathrm{mg} / \mathrm{a}$ 
て検討されてきている.Shackelford ${ }^{44)}$ (1986) は 上気道感染を繰り返す小児では, IgG2 が低值 または欠損していると報告している. Freijd ${ }^{45)}$ （1985）は血清 IgG2 レベルが健康乳児と比較し て otitis-prone の乳児の方が低值であると報告 した。しかし，著者46）（1987）は慢性渗出性中 耳炎患児の血清 IgG subclass を免疫拡散法に て測定したが，IgG1，IgG2 に低値や欠損を認 めず，すべて正常範囲であった（表 1 ）. $\mathrm{Kalm}^{47)}$ (1984) は反復性中耳炎児の肺炎球菌抗 体価を肺炎球菌のタイプ別に測定して健康小児 に比べて低值であることを見出している．しか し免疫不全の状態ではなく抗体産生能が遅延し ているだけであり, 抗体産生は各肺炎球菌抗原 性と関連すると報告している. RynnelDagöö ${ }^{48)}$ (1986) は肺炎球菌抗体価を IgG subclass 別に健康人の各年齢層で検討した. 臍 帯血と成人血液は IgG2 肺炎球菌抗体価は同じ であるが, 乳児から 4 〜歳までは低值で 7 15歳で成人值に達すると報告している，母体か ら胎盤を通じて移行した免疫グロブリンが消失 していく生後 6 力月以後に急性中耳炎の発症頻 度が高くなっていくのもこの点と関係がある. 著者46)49）（1987，1988）も慢性渗出性中耳炎患 児の血清と出産時の母体血と臍帯血を採取し,

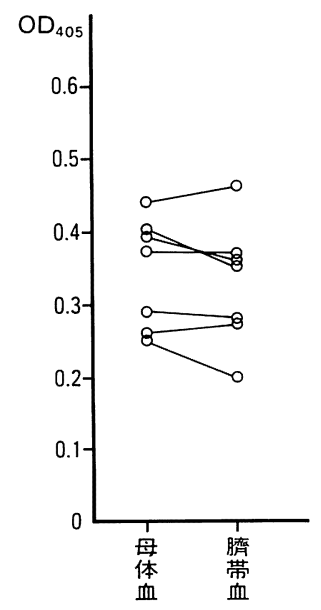

図 4 出産時における健康母体血と臍帯血の抗肺炎 球菌 IgG 抗体価
23 種類の肺炎球菌リポ多糖体を含む肺炎球菌ワ クチン (Pneumovax ${ }^{(\mathbb{R})}$ )を用いて血清抗肺炎球菌 抗体価を ELISA にて測定した（図 4, 図 5 ). 特異的抗肺炎球菌 IgG 抗体は, IgG の胎盤移 行により新生時は母親と同等の抗体価があり, 感染に対する抵抗を保持している。一方滲出性 中耳炎患児においては, 全例に肺炎球菌抗体価 が低いのではなく 1 歳から 5, 6 歳頃までが低 值である.そして年秢と共に抗体価が増加し, 8 歳を過ぎると成人の抗体価に等しくなってい る. 特異的抗肺炎球菌 IgM 抗体は全年齢を通

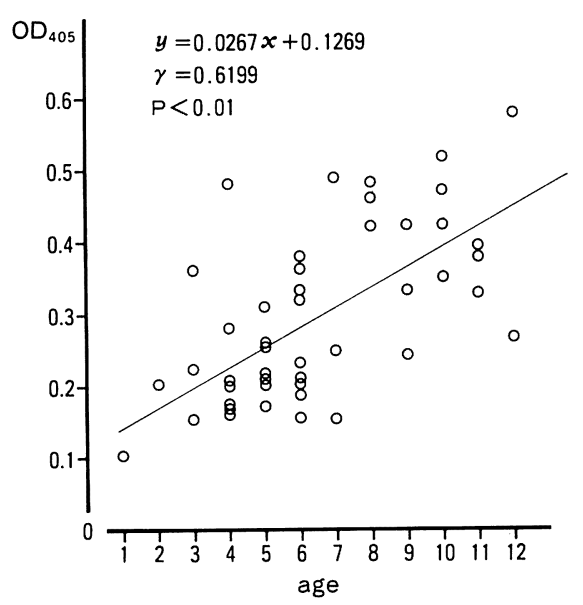

図 5 慢性渗出性中耳炎患児に括ける抗肺炎球菌 $\operatorname{IgG}$ 抗体価と年秢との関係

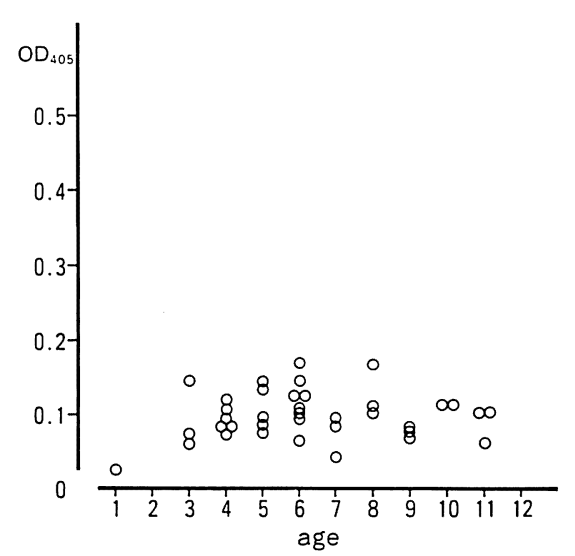

図 6 慢性渗出性中耳炎患児の抗肺炎球菌 IgM 抗体 価 
じて低值であった（図 6 ). IgA 抗体は同じく 低値または同定できなかった（図 7 )。さらに 各肺炎球菌の Type 別の血清 IgG 抗体価を測定 した（表 2). Type 23F 肺炎球菌に対する抗 体価は他の capsular antigen に比べて低值であ った。これは Type 23 肺炎球菌の免疫原性が 低いことによるのかもしれない. Type 3， Type 6A と Type 19A は年齢と共に増加傾向 を示した. しかも Type 3, Group 6, Group 19, Group 23 が主要な起炎菌とするならば年齢と 共に抗体価が上昇するといらことは若年児の細 菌抗体産生能が十分発達していないことを示す ものである.Mogi ${ }^{50)}$ (1986) は小児末梢血の

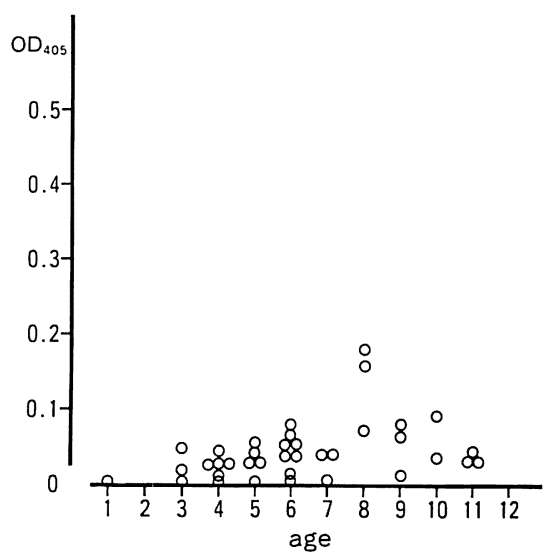

図 7 慢性渗出性中耳炎患児の抗肺炎球菌 IgA 抗体 価

表 2 肺炎球菌型別の血清 $\operatorname{IgG}$ 抗体価

\begin{tabular}{|c|c|c|c|c|c|c|c|}
\hline age & type 3 & type $6 \mathrm{~A}$ & type 6B & type $9 \mathrm{~V}$ & type $19 A$ & type 19F & type $23 F$ \\
\hline $1(1)$ & $0.054 *$ & 0.188 & 0.050 & 0.042 & ND & 0.064 & 0.030 \\
\hline $2(1)$ & 0.045 & 0.131 & 0.006 & 0.007 & 0.185 & 0.217 & 0 \\
\hline $3(3)$ & 0.181 & 0.176 & 0.194 & 0.087 & 0.189 & 0.116 & 0.103 \\
\hline $4(7)$ & 0.168 & 0.109 & 0.040 & 0.058 & 0.153 & 0.152 & 0.078 \\
\hline $5(7)$ & 0.181 & 0.134 & 0.102 & 0.188 & 0.196 & 0.178 & 0.035 \\
\hline $6(9)$ & 0.153 & 0.164 & 0.115 & 0.157 & 0.193 & 0.144 & 0.105 \\
\hline 7 (3) & 0.338 & 0.239 & 0.071 & 0.087 & 0.239 & 0.127 & 0.139 \\
\hline $8(3)$ & 0.600 & 0.251 & 0.248 & 0.272 & 0.144 & 0.248 & 0.100 \\
\hline $9(3)$ & 0.354 & 0.130 & 0.080 & 0.136 & 0.266 & 0.206 & 0.046 \\
\hline $10(4)$ & 0.377 & 0.278 & 0.250 & 0.302 & 0.272 & 0.164 & 0.059 \\
\hline 11 (3) & 0.121 & 0.194 & 0.135 & 0.114 & 0.247 & 0.097 & 0.152 \\
\hline $12(2)$ & 0.334 & 0.302 & 0.166 & 0.087 & 0.238 & 0.111 & 0.227 \\
\hline
\end{tabular}

helper T cell の Streptococcal cell wall に対す る反応を検討し，低年㱓児では低く加龄ととも に増大することを証明した。このことより細菌 抗体産生能の未熟性は B cell が分化, 増殖して 抗体産生細胞になるために必要な helper T cell の機能にも関係している.

以上より，慢性滲出性中耳炎患児は必ずしも 免疫不全状態ではなく, 機能低下の状態であり, それは一過性のものと考兄られ。急性中耳炎 から慢性渗出性中耳炎への発症機序を考えた場 合，急性中耳炎を起こした時の宿主防御能の程 度と起炎菌の抗原性や virulence との力関係に 依存するものと思われる. 宿主側の防御能が弱 ければ細菌処理が不十分となり中耳腔に細菌や 菌体成分が残存し，抗原持続状態のため滲出性 中耳炎へ移行していくと考えられる．このため 急性中耳炎の発症しやすい乳幼児の免疫力を上 げることが滲出性中耳炎の予防にもなると考え られる，それ故他の細菌感染予防と同様にワク チン療法が注目されている. しかし，Karma ${ }^{511}$ (1985) は生後 6 力月から11力月児に肺炎球菌ワ クチンを接種したが効果は良くなかった。

$\mathrm{Kalm}^{52)}$ (1986) も，3 歳以下の反復性中耳炎児 と健康児に14価ワクチンを皮下注射したがどち らの小児にも肺炎球菌抗体価の上昇を認めなか った．年長児や成人に有用なワクチンも，中耳 炎罹患率の高い乳幼児に無効であることと， Koskla ${ }^{53)}$ (1986) らが指摘するように全身的抗 体価の上昇を期待できても，局所免疫を賦活す ることはできなかった，他の百日咳，破傷風， ジフテリアなどのワクチンと同じよらに免疫応 答の低い乳幼児にも有効な肺炎球菌ワクチンの 改良が望まれる。また上気道の Waldeyer 扁桃 輪や分泌型 $\operatorname{IgA}$ の局所免疫も粘膜感染防御を 担ら要素であるため, mucosal immunityにつ いても今後の重要な研究課題と考える.

\section{参考文献}

1) Politzer A : Diagnose und therapie der Ansammlung seroser flussigkeit in der Trommelhohle. Wien Med Wochenschr 17 : 244 
247, 1867.

2) Senturia B, et al : Studies concerned with tubotympanitis. Ann Otol Rhinol Laryngol $67: 440 \sim 467,1958$.

3) Sade J : Secretory otitis media and its sequelae. Monographs In Clinical Otolaryngology Vol 1. pp 125 144, Churchill Livingstone, New York, 1979.

4) Bluestone CD and Klein JO : Otitis Media in Infants and Children. pp 45 68, WB Saunders, Philadelphia, 1988.

5) DeMaria TF, et al : Endotoxin in middle ear effusion from patients with chronic otitis media effusion. RECENT ADVANCES IN OTITIS MEDIA WITH EFFUSION (ed by Lim, et al) pp 123 125, BC Decker, Philadelphia-Toronto, 1984.

6）飯野ゆき子，他：中耳滲出液のエンドトキシン 検索. 臨床耳科 $11: 354 \sim 355,1984$.

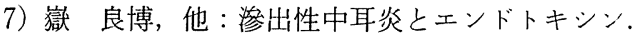
耳鼻臨床 78 : 577〜 581, 1985.

8) Palva $T$ : Immune complexes in middle ear fluid in chronic secretory otitis media. Ann Otol Rhinol Laryngol 92 : 42 44, 1983.

9) Palva $T$, et al : Pneumococcal immune complexes and clinical course of secretory otitis media. Int J Pediatric Otorhinolaryngol 10 : 21 26, 1985.

10）原田輝彦，他：中耳貯留液の Immune complex そついて. Ear Res Jpn 15 : 43〜45, 1984.

11）嶽 良博, 他: 中耳炎と肺炎球菌血清型分布. Ear Res Jpn 19 : 287 289, 1988.

12) Kokko E, et al : Chronic secretory otitis media in children. Acta Otolaryngol Suppl $327: 1 \sim$ 44, 1974.

13) Teele DW, et al : Epidemiology of otiltis media in children. Ann Otol Rhinol Laryngol 89 Suppl $68: 5 \sim 6,1980$.

14) Kaneko $Y$, et al : Incidence of secretory otitis media after acute imflammation of the middle ear cleft and the upper respiratory tract. RECENT ADVANCES IN OTITIS MEDIA WITH EFFUSION (ed by Lim, et al) pp 34 36, BC Decker Philadelphia-Toronto, 1983.
15) Fulghum RS, et al : Longitudinal studies of experimental otitis media with Haemophilus influenzae in the gerbil. Int $\mathrm{J}$ pediatr Otorhinolaryng $9: 101 \sim 114,1985$.

16) Mills $R$, et al : Middle-ear effusion following acute otitis media in the chinchilla animal model. Journal of Laryngology and Otology $100: 255 \sim 261,1986$.

17) Barenkamp SJ : Protection by serum antibodies in experimental nontypable haemophilus influenzae otitis media. Infact Immun $52: 572 \sim 578,1986$.

18) Giebink GS, et al : Experimental otitis media due to streptococcus pneumoniae; immunopathogenic response in the chinchilla. J Infect Dis 134 : 595 604, 1976

19) Giebink GS, et al : Comparison of otitis media due to type 3 and 23 streptococcus pneumoniae in the chinchilla model. J Infect Dis 136 Suppl : 191 195, 1977.

20) Meyerhoff WL, et al : Experimental pneumococcal otitis media; a histopathologic study. Otolaryngol Head Neck Surg 88 : 606 612, 1980.

21) Fulghum RS, et al : Experimental pneumococcal otitis media; longitudinal studies in the gerbil model. Int $\mathrm{J}$ Pediatric Otorhinolaryngol $10: 9 \sim 20,1985$.

22) Hermansson $A$, et al : A rat model for pneumococcal otitis jmedia. Am J Otolaryngol $9: 97 \sim 101,1988$.

23）村井貞子, 他 : 肺炎球菌の血清型別方法の菌型 分布について.臨床と微生物 15:34～38, 1988.

24）福見秀雄, 他 : 肺炎球菌ワクチシの臨床応用に 関する研究一わが国に打ける血清型分布一。感 染症学雑誌 $58: 39 \sim 53,1984$.

25）嵓 良博, 他：上気道感染症と肺炎球菌血清型 分布. 日耳鼻 $92: 228 \sim 232,1989$.

26) Leinonen MA, et al : Detection of pneumococcal capsular polysaccharide antigens by latex agglutination, counter-immunoelectrophoresis and radioimmunoassay in middle ear exudates in acute otitis media. J Clin Microbio $11: 135$ $\sim 140,1980$. 
27) Borgono JM, et al : Vaccination and revaccination with polyvalent penumococcal polysaccharide vaccines in adults and infants. Proc Soc Exp Biol Med 157 : 148 154, 1978.

28) Cowan MJ, et al : Pneumococcal polysaccharide immunization in infants and children. Pediatrics $62: 721 \sim 727,1978$.

29) Pedersen FK, et al : Detection of antibodies to pneumococcal capsular polysaccharides by enzyme-linked immunosorbent assay. J Clin Microbiol $15:$ 372 378, 1982.

30) Watanabe $\mathrm{N}$, et al : Experimental otitis media in chinchillas II; comparison of the middle ear immune responses to $\mathrm{S}$ pneumoniae types 3 and 23. Ann Otol Rhinol Laryngol Suppl $93: 9$ $\sim 16,1982$.

31）嶽 良博，他：肺炎球菌型別による実験的中耳 炎. Ear Res Jpn 20 : 161 162, 1989.

32) Yamaguchi $T$, et al : Antibody response in experimental haemophilus influenzae otitis media. Arch Otolaryngol Head and Neck Surg 112 : 554 557, 1986.

33) Barenkamp SJ, et al : Protection by serum antibodies in experimental nontypable haemophilus influenzae otitis media. Infect Immun 52 : $572 \sim 578,1986$.

34) Shurin PA, et al : Prevention of pneumococcal otitis media in chinchillas with human bacterial polysaccharide immune globulin. J Clin Microbiol 26 : 755 759, 1988.

35) Lowell SH, et al : Experimental otitis media following middle ear inoculation of nonviable streptococcus pneumniae. Ann Otol $89: 479$ $\sim 482,1980$.

36) DeMaria TF, et al : Experimental otitis media with effusion following middle ear inoculation of nonviable $h$ influenzae. Ann Otol Rhinol Laryngol $93: 52 \sim 56,1984$.

37) Okazaki $\mathrm{N}$, et al : Experimental otitis media with effusion induced by nonviable $\mathrm{H}$ influenzae cytological and histol ogical study. Am J Otolaryngol $5: 80 \sim 92,1984$.

38）野々村直文, 他 : H influenzae type b の内毒素 による実験的參出性中耳炎. Ear Res Jpn 16：
372 374, 1985.

39）野々村直文，他：Hemophilus influenzae の細 胞壁による㬰験的滲出性中耳炎. Ear Res Jpn $18: 344 \sim 347,1987$

40) Giebink GS, et al : Polymorphnuclear leukocyte dysfunction in children with recurrent otitis media. J PEDIATR 94 : 13 18, 1979.

41) Ichimura $K$ : Neutrophil chemotaxis in children with recurrent otitis media. Int $\mathrm{J}$ Pediatric Otorhinolaryngol $4: 47 \sim 55,1982$.

42) Karvhev LS, et al : Phagocytic activity and bactericidal capacity of polymorphonuclear leukocytes in children with recurrent otitis media. Int J Pediatric Otorhinolaryngol 10 : 165 170, 1985.

43）飯野ゆき子，他：中耳に护るエンドトキシン のクリアランス. Ear Res Jpn 19:177〜179, 1988.

44) Shackelford PG, et al : Spectrum of IgG2 subclass deficiency in children with recurrent infections; prospective study. J PEDIATR $108: 647 \sim 653,1986$.

45) Freijd A, et al : A prospective study demonstrating an association between plasma IgG2 concentrations and susceptibility to otitis media in children. Scand J Infect Dis $17: 115$ $\sim 120,1985$.

46）㒛 良博, 他：滲出性中耳炎患者における肺炎 球菌抗体の同定. Ear Res Jap $18: 372 \sim 374$, 1987.

47) Kalm $\mathrm{O}$, et al : Pneumococcal antibodies in families with recurrent otitis media. Int Archs Allergy appl Immun $75:$ 139 142, 1984.

48) Rynnel-Dagöö $B$, et al : Pneumococcal antibodies of different immunogobulin subclasses in normal and IgG subclass deficient individuals of various ages. Acta Otolaryngol $101: 146 \sim 151,1986$

49) Dake $Y$, et al : Antibody activity against pneumococcal antigens and the level of serum IgG subclass of otitis media with effusion. RECENT ADVANCES IN OTITIS MEDIA (ed by David J Lim, et al) BC Decker, PhiladelphiaToronto, pp 171 173, 1988. 
50) Mogi G, et al : Development of the immune system in children. Rhinology $24: 15 \sim 24,1986$.

51) Karma $P$, et al : Prevention of otitis media in children by pneumococcal vaccination. Am J Otolaryngol $6:$ 173 184, 1985.

52) Kalm O, et al : Antibody activity before and after pneumococcal vaccination of otitis-prone and non-otitis-prone children. Acta Otolaryngo (Stockh) $101:$ 467 474, 1986.

53) Koskela M, et al : Antibody response of young children to parenteral vaccination with pneumococcal capsular polysaccharides; a comparison between antibody levels in serum and middle ear effusion. Pediatr Infect Dis, $5: 431$ $\sim 434,1986$.

$\left(\begin{array}{l}\text { 別刷請求先 : 訔 良博 } \\ \mathbf{T} 640 \text { 和歌山市七番丁 } 27 \\ \text { 和歌山県立医科大学耳鼻咽喉科学教室 }\end{array}\right)$ 